SVU- International Journal of Veterinary Sciences, 2 (2): 27-44, 2019.

Print ISSN: 2535-1826

\title{
Effect of Probiotic on Growth Performance, Carcass Traits, and Clinical Health Parameters of Broilers Reared under Heat Stress in Upper Egypt
}

\section{Eslam Khalifa $^{1 *}$, Mootaz Abdel-Rahman², Khaled Ghareeb ${ }^{1}$}

${ }^{1}$ Department of Animal Behavior and Management, Faculty of Veterinary Medicine, South Valley University, Qena, Egypt, ${ }^{2}$ Department of Animal behavior and Hygiene, Faculty of Veterinary Medicine, Minya University, Minya, Egypt.

\section{Abstract}

This study was conducted to investigate the effect of probiotic (PROBAC plus ${ }^{\circledR}$ ) supplementation on growth performance, carcass characteristics, and clinical health parameters of broilers reared under high temperature $\left(32-35^{\circ} \mathrm{c}\right)$ from age of 22 to 42 day. A total of 120 broiler chicks were divided into 4 groups at age of one day. The first group was control (fed with basal diet), second was broilers reared at high temperature (fed with basal diet), third was broilers reared at high temperature (fed basal diet + probiotic) and fourth was probiotic group (control + probiotic). Growth performance was determined weekly. At day 42, 10 birds from each group were randomly selected and slaughtered to determine the carcass characteristics and to collect blood samples. Serum blood biochemical parameters and thyroid hormones were estimated. The obtained results showed that heat stress have reduced the performance, carcass traits and showed alterations in clinical biochemical parameters. Addition of probiotic to diets of birds reared with or without stress enhanced growth performance, carcass traits and improved clinical blood parameters. The results suggest that probiotic can be used to counteract the adverse effects of heat stress in addition to its efficacy as growth promoter.

Keywords: Blood Biochemicals, Broiler Chicken, Growth Performance, Heat Stress, Probiotic.

DOI: $10.21608 /$ svu.2019.11221.1012

Received: May 7, $2019 \quad$ Accepted: June 22, 2019

Published: June 27, 2019

*Corresponding Author: Eslam Khalifa Hassan Ahmed E-mail: eslam_kh@vet.svu.edu.eg

Citation: Khalifa et al., Effect of Probiotic on Growth Performance, Carcass Traits, and Clinical Health Parameters of Broilers Reared under Heat Stress in Upper Egypt. SVU-IJVS 2019, 2 (2): $27-$ 44.

Copyright: (C) Khalifa et al. This is an open access article distributed under the terms of the creative common attribution license, which permits unrestricted use, distribution and reproduction in any medium provided the original author and source are created.

Competing interest: The authors have declared that no competing interest exists. 


\section{Introduction}

Poultry industry during the past two decades became one of the most dynamic and ever expanding sectors in the world and is regarded as a vital source of meat for human being. Poultry production in tropical countries faces a big challenge due to higher ambient temperature that can lead to heat stress (HS) (Farghly et al., 2018). The negative impact of heat stress on poultry welfare has recently attracted increasing public awareness and concern. Heavy economic losses have been reported due to increased mortality and decreased productivity in response to HS (Shah et al., 2019).

Broiler chickens are homoeothermic; they keep their body temperature within a slight range irrespective to ambient temperature. When prevailing temperatures rise above the comfort zone (from $22^{\circ} \mathrm{C}$ up to $27^{\circ} \mathrm{C}$ ), as they experience HS (He et al., 2018). Thermal comfort indices such as the temperature-humidity index (THI) integrate the effects of temperature and humidity. Currently, THI is commonly used to quantify the degree of heat stress and provides a possible way to predict the effects of thermal conditions on broilers' performance (Habeeb et al., 2018). Generally, when THI exceeds approximately $21^{\circ} \mathrm{C}, \quad$ bird's body temperature increased up to $1.7^{\circ} \mathrm{C}$ above nominal body temperature and leads to HS (Purswell et al., 2012). Heat stress is characterized by endocrine disorders, reduced metabolic rate, lipid peroxidation, decreased feed consumption, negative alteration in nutrient digestibility, absorption and metabolism, decreased body weight (BW) gain, higher feed conversion ratio (FCR), alteration of blood parameters, reduced weight of internal organs and mortality (Abdel-Wareth et al., 2018, Ghazi et al., 2012, He et al., 2018,
Rhoads et al., 2013, Rehab 2011, Sugiharto et al., 2017).

Poultry scientists are working continuously and intensively to provide solutions for poultry producers to alleviate the significant problems such as rearing birds under heat stress in poultry farms. The use of antibiotics in the poultry industry was beneficially as therapeutic, prophylactic and growth promotion (Ohimain and Ofongo, 2012). However, the presence of antibiotic residues in poultry products may have harmful effects on consumers. The residues of antibiotics can cause resistance of human flora and pathogenic microbes to those groups of antibiotics (McEwen et al., 2018). Thus, with increasing the concerns about antibiotic resistance, the usage of antimicrobial growth-promoters in animal feed were banned by Europe (EU) in 2006 to protect public health, and this ban drew a great attention of other countries and international organizations (Hao et al., 2016). It is clear that there is an increasing interest to find alternatives to the use of antibiotics in poultry production (Pournazari et al., 2017). Moreover, Market trends have also shown an increased interest in organic and antibioticfree meat products by consumers all over the world (Eckert et al., 2010).

It was shown that feed additives were able to affect animal performance and welfare, particularly through the modulation of the gut microbiota which plays a critical role in maintaining host health (Dibaji et al., 2014). A balanced gut microbiota constitutes an efficient barrier against pathogen colonization, produces metabolic substrates (e.g. vitamins and short-chain fatty acids) and stimulates the immune system in a non-inflammatory manner (Sugiharto et al., 2017). Probiotics, prebiotics, synbiotics and organic acids are 


the most common dietary

supplementations. Their main effects are the improved resistance to bacterial colonization and enhanced host mucosal immunity; thus resulting in a reduced pathogen load, and an improved health status of the animals (Mahrose et al., 2019).

Over the years the word probiotic has been used in several different ways. Probiotics are live microorganisms of nonpathogenic and nontoxic in nature, which when administered through the digestive route, are favorable to the host's health (Mohammed et al., 2019). According to the currently adopted definition by Food and Agriculture Organization (FAO) and World Health Organization (WHO), probiotics are: "live microorganisms which when administered in adequate amounts confer a health benefit on the host" (WHOLFAO, 2001). It was reported that probiotics have a positive impact on the poultry performance, improve microbial balance and synthesize vitamins, release bacteriocins, improve feed consumption in layers and broilers and altering bacterial metabolism (Cramer et al., 2018, Eckert et al., 2010, Sugiharto et al., 2017). Due to the observed positive effects of probiotic, it is now widely used as a growth promoter in poultry industry. However, there are rare and varying results about its effect on broilers reared under heat stress. Therefore, this study was performed to evaluate the efficacy of probiotic feed additive to counteract the adverse effects of heat stress on growth performance, carcass traits, and clinical health parameters in broiler chickens.

\section{Materials and Methods}

\section{Birds, housing and management:}

A total of one hundred twenty (120) one day old commercial broiler chicks (male and female, Ross 308) were obtained from a commercial hatchery in Egypt. Chicks were reared in the experimental farm of Faculty of Veterinary Medicine, South Valley University, Qena, Egypt, during the period between November to December 2014. Birds were divided into 4 groups (30 birds / group) and housed in pens with wood shavings floor. The shavings were kept dry throughout the experimental period of six weeks by routine replacement of the spoiled litter. Four pens were $3 \mathrm{~m}^{3}$ $(2 \times 1.5 \times 2 \mathrm{~m})$ (length $\times$ width $\times$ height $)$. Stocking density was 10 birds $/ \mathrm{m}^{2}$. The pens were disinfected before housing of birds with TH4 (Sogeval, France). All manure materials were removed and scrubbed from poultry house. Dust materials were removed from windows, floors, ceiling, walls and ventilation shafts using water and high pressure sprayers, then disinfected by TH4 that were previously diluted to 1:200. All equipment (feeders and drinkers) and removable fittings were demounted and taken out of the building and soaked in 1:200 TH4 dilution baths. The house units were washed with 1:200 TH4 dilutions. Spraying of quicklime in the ground to kill parasites and its' eggs such as coccidia. Day to day management was carried out for keeping the facility cleaned. After daily cleaning, cleaned feeders and drinkers were dried and filled with feed and water respectively.

\section{I.1. Lighting:}

Continuous lighting program (23 L: 1 D) was used as described earlier (Olanrewaju et al., 2006). Sixty watt bulb was suspended $2.20 \mathrm{~m}$ in the middle of each pen. Light intensity at the level of the birds was approximately $2.66 \mathrm{lux} / \mathrm{m}^{2} /$ second. 
SVU-IJVS, 2 (2): 27-44

\section{I.2. Temperature of poultry house:}

Temperature was set initially at $35^{\circ} \mathrm{C}$ and gradually reduced at a rate of $2-5^{\circ} \mathrm{C} /$ week till reach $22^{\circ} \mathrm{C}$ at the fourth week as described previously (Ghareeb et al., 2014). Afterword, at $5^{\text {th }}$ and $6^{\text {th }}$ weeks, the temperature was kept at $22^{\circ} \mathrm{C}$. Ambient temperature was determined by maximum and minimum thermometer, where the readings were taken every day. Heat was provided by electrical heater. For the two groups of heat stress, the temperature was kept at $32-35^{\circ} \mathrm{C}$ at week 4,5 and 6 of age and the average THI was 31.427 . THI was calculated according to the formula described by Farghly et al. (2018).

\section{I.3. Humidity:}

Indoor relative humidity was measured by using wall mount thermohygrometer. Average relative humidity ranged between 60 to $70 \%$ as described earlier (Tao and Xin, 2003).

\section{Diet, feeding and vaccination program:}

Birds of all groups were fed a commercial diet (Alaaf ALmagd, Alarabia Lell-Alaaf, Quesna, El Monofya, Egypt). Chicks were fed starter diet from 1- $14 \mathrm{~d}$, grower diet from 15- $28 \mathrm{~d}$ and finisher diet 29- $42 \mathrm{~d}$ of age. The birds were fed mash diet ad libitum and given free access to fresh and clean water throughout the experimental period. Diet composition was set according to National Research Council, NRC (1994). The basal diet composed of yellow corn, soy bean meal, corn gluten, soy oil, dicalcium phosphate, lime stone, common salt, sodium bicarbonate, vitamins, minerals, choline chloride, DL-Methionine and L-lysine. The chemical composition of the basal diet is summarized in Table (1).
Table (1): Diet chemical composition.

\begin{tabular}{cccc}
\hline & Starter & Grower & Finisher \\
\hline $\begin{array}{c}\text { Crude protein } \\
(\%)\end{array}$ & 23 & 21 & 19 \\
\hline Crude fat $(\%)$ & 5.92 & 6.62 & 6.86 \\
\hline ME (kcal/kg) & 3020 & 3100 & 3200 \\
\hline $\begin{array}{c}\text { Crude fiber } \\
(\%)\end{array}$ & 3.76 & 3.46 & 3.20 \\
\hline
\end{tabular}

Probiotic groups were fed with commercial probiotic mixture (PROBAC plus, Animal Health Care company, Reg. No.:M.O.A:9948, Cairo, Egypt) (1g / kg diet) from $1 \mathrm{~d}$ old to $42 \mathrm{~d}$ of age. Each gram composed of 20 million of Lactobacillus Acidophilus, Plantarum, Bervis and Bifidobacteria also contains $100 \mathrm{mg}$ of Saccharomyces Cerevisiae. It contains digestive enzymes such as amylase, beta- glucanase, hemicillulase and cellulase. PROBAC plus releases antibiotic analogus in digestive tract such as hisin, reuterin, bulgaricin and acidophilin.

At the first 12 hours of chicks arrival, chicks were allowed to drink water with addition of oral rehydration salts (REHYDRAN - N 5.5 g Sachets) manufactured by (SEARLE pharmaceutical company). It is composed of glucose anhydrous $4.00 \mathrm{~g}$, tri - sodium citrate anhydrous $0.51 \mathrm{~g}$, sodium chloride $0.70 \mathrm{~g}$ and potassium chloride $0.30 \mathrm{~g}$ for each sachet of the product $(5.5 \mathrm{~g})$. Water soluble powder of vitamins and minerals (Vetaminolyte Plus, Zagro Singapore pte, Singapore) was given 3 days / week (1g / $3 \mathrm{~L}$ of water). At age of 7 days, all chicks were vaccinated intra-ocular by Himmvac Newcastle B1 Live Vaccine (KBNP Inc, Korea). At age of 12 and 23 days, all birds were vaccinated via drinking water against Gumboro (Infectious Bursal Disease) with (CEVAC TRANSMUNE IBD vaccine, Ceva Company, France) 
after addition of dried skim milk. At age of 28 days, all chicks were vaccinated against Newcastle Disease via drinking water (B1 Type, LaSota Strain, Live Virus, Zoetis Inc., Kalamazoo, MI 49007, United States of America) after addition of dried skim milk.

\section{Experimental design.}

This study was arranged into four groups with two main variations; addition of probiotic to basal diet and heat stress.
The first group was control (basal diet), the second was heat stress group (32$35^{\circ} \mathrm{C}$ ), the third was heat stress group with addition of probiotic to basal diet and the fourth was probiotic group (basal diet + probiotic). The experimental design is summarized in Table (2).

It consists of two main variations; heat stress, and addition of probiotic to basal diet either for control birds or heat stress group.

Table (2): The main experimental variations

\begin{tabular}{c|cccc}
\hline Variations & $\begin{array}{c}\text { Control } \\
\text { group }\end{array}$ & Heat stress group & $\begin{array}{c}\text { Heat stress } \\
+ \\
\text { Probiotic }\end{array}$ & Probiotic group \\
\hline Diet & Basal diet & Basal diet & Basal diet with probiotic & $\begin{array}{c}\text { Basal diet with } \\
\text { probiotic }\end{array}$ \\
\hline Temperature & $\begin{array}{c}\text { Normal } \\
22^{\circ} \mathrm{C}\end{array}$ & $\begin{array}{c}\text { High temperature } \\
32-3^{\circ} \mathrm{C}\end{array}$ & $\begin{array}{c}\text { High temperature } \\
32-3^{\circ} \mathrm{C}\end{array}$ & $\begin{array}{c}\text { Normal } \\
2^{\circ} \mathrm{C}\end{array}$ \\
\hline
\end{tabular}

\section{IV-Broiler performance.}

Feed intake (FI), feed conversion ratio (FCR) and live body weight (LBW) were determined for each group separately.

\section{IV.1. Body weight (BW) (g/bird/week).}

Chicks were individually weighed at one day-old (initial BW) and weekly throughout the experimental period (1 to 42 days of age).

IV.2. Body weight gain (BWG) ( $g$ / bird / week).

The live body weight gain was calculated every week by subtracting the initial weight from the initial weight from its present weight every week.

IV.3. Feed intake (FI) (g/bird/week).
Chicks in each group were provided with a certain amount of feed weekly and rest of feed was weighed at the end of each week. The difference between feed given and rest feed was calculated. The average amount of feed intake was calculated by dividing the weekly consumed feed to the number of birds in each group at this week.

\section{IV.4. Feed conversion ratio (FCR / week).}

Feed conversion ratio was calculated weekly by dividing the average feed consumption per bird to the average body weight gain per bird.

\section{$V$ - Slaughtering and blood sampling:}

At the end of the experiment at (42 day old), 10 birds from each group were randomly selected and slaughtered using a 
sharp knife. During slaughtering, $3 \mathrm{ml}$ of blood from (5 birds / group) were collected from each bird in tubes without anticoagulant. The blood samples were cooled to approximately $4^{\circ} \mathrm{C}$ using icepacks and were transferred to the laboratory within two hours after blood collection and then centrifuged at 3000 r.p.m for 10 minutes and serum was separated in Eppendorf's tubes using micropipette. The collected sera were kept at $-20^{\circ} \mathrm{C}$, until analysis.

VI- Carcass Characteristics and weight of selected organs.

After slaughtering, weight of carcass was determined (carcass weight). The head, neck and legs were removed then carcasses were manually eviscerated and weighed (eviscerated weight). The weight of heart, empty gizzard, liver and spleen was also calculated.

\section{VII- Blood parameters.}

\section{VII.1- Clinical serum biochemicals:}

Serum biochemicals were estimated by a digital-VIS / ultraviolet spectrophotometer (723C Visible Spectrophotometer, Shanghai Phenix Optical Scientific Instrument Co., Ltd, China) in the laboratory of physiology department, faculty of veterinary medicine, South Valley University, Qena, Egypt.

\section{VII.1.1- Serum total protein $(g / d L)$.}

Serum total proteins were assayed by a colorimetric method using a commercial kit (spectrum total protein diagnostic kits, Egyptian company for biotechnology, Egypt).

Serum protein $(\mathrm{g} / \mathrm{dL})=(\mathrm{A}$ specimen $/ \mathrm{A}$ Standard) x 6.
VII.1.2- Serum albumin ( $g / d L)$ :

Serum albumin was assayed by a colorimetric method using a commercial kit (spectrum albumin diagnostic kits, Egyptian company for biotechnology, Egypt).

Albumin $(\mathrm{g} / \mathrm{dL})=(\mathrm{A} \quad$ specimen $/ \mathrm{A}$ Standard) $x 4$.

\section{VII.1.3-Serum globulin (g/dL):}

Serum globulin was calculated by subtraction serum albumin from serum total protein (Rocco, 2005).

\section{VII.1.4-Albumin/globulin $(A / G)$ ratio:}

Albumin/globulin ratio was calculated by dividing albumin concentration $(\mathrm{g} / \mathrm{dl})$ to globulin concentration $(\mathrm{g} / \mathrm{dL})$.

\section{VII.1.5- Serum cholesterol level $(\mathrm{mg} / \mathrm{dL})$ :}

Serum cholesterol was assayed by a colorimetric method using a commercial kit (spectrum albumin diagnostic kits, Egyptian company for biotechnology, Egypt).

Serum cholesterol $(\mathrm{mg} / \mathrm{dL})=(\mathrm{A}$ specimen/A Standard) x 200.

\section{VII.1.6- Serum glucose level ( $\mathrm{mg} / \mathrm{dL})$ :}

Serum glucose was assayed by a colorimetric method using a commercial kit (spectrum albumin diagnostic kits, Egyptian company for biotechnology, Egypt).

Serum glucose $(\mathrm{mg} / \mathrm{dL})=($ A specimen $/ \mathrm{A}$ Standard) x 100

VII.1.7- Serum urea level $(m g / d L)$ : 
Khalifa et al., 2019

SVU-IJVS, 2 (2): 27-44

Serum urea was assayed by a colorimetric method using a commercial kit (bioMerieux, France).

\section{VII.1.8- Serum creatinine level $(\mathrm{mg} / \mathrm{dL})$ :}

Serum creatinine was assayed by a colorimetric method using a commercial kit (bioMerieux, France).

VII.1.9- Serum aspartate aminotransferase (AST) level (IU/dL):

Serum AST was assayed by a colorimetric method using a commercial kit (spectrum AST diagnostic kits, Egyptian company for biotechnology, Egypt).

VII.1.10- Serum alanine aminotransferase (ALT) level (IU/dL):

Serum ALT was assayed by a colorimetric method using a commercial kit (spectrum ALT diagnostic kits, Egyptian company for biotechnology, Egypt).

\section{VII.2- Serum hormones:}

Serum T3 and T4 were estimated by stat fax-2100 (ELISA kits Awareness technology, INC, USA).

\section{VII.2.1- Triiodothyronine (T3) ( $\mathrm{ng} / \mathrm{mL})$ :}

Serum triiodothyronine $\left(\mathrm{T}_{3}\right)$ was assayed by a solid phase enzyme immunoassay using total $\mathrm{T}_{3}$ commercial ELISA kits (Catalog Number; BC-1005; BioCheck, Inc .323 Vintage Park Drive. Foster City, CA 94404, USA).

VII.2.2- Thyroxin (T4) $(\mu g / d L)$ :
Serum Thyroxin $\left(\mathrm{T}_{4}\right)$ was assayed by a solid phase enzyme immunoassay using total $\mathrm{T}_{4}$ commercial ELISA (Catalog Number; BC-1007; BioCheck, Inc .323 Vintage Park Dr. Foster City, CA 94404, USA).

\section{VIII- Statistical analysis:}

Data was provided as means $\pm \mathrm{SE}, \mathrm{n}$ represented the number of broiler chicks investigated. Statistical program SPSS (Statistical Package for the Social Sciences) version 16 was used for statistical analysis of data. A described statistic including mean value for feed intake and feed conversion ratio were calculated. One way analysis of variance (ANOVA) was performed followed by least significant difference test (LSD) to find the significance between experimental groups. A level of probability $(P)$ of $\leq 0.05$ was considered significant and a level of $P$ $\leq 0.1$ was considered a tendency toward significance.

\section{Results}

I- Growth performance:

I.1- Body weight $(B W)$ :

Heat stress reduced the BW of broilers at the fifth and sixth weeks $(1802 \pm 28$ and $1883 \pm 31 \mathrm{~g}$, respectively) compared with control birds $(1967 \pm 41$ and $2240.5 \pm 49 \mathrm{~g}$, respectively). Addition of probiotic to HS broilers counteracted this effect at the sixth week of age compared with HS broilers $(2332 \pm 28 \mathrm{~g}$ versus $1883 \pm 31 \mathrm{~g})$ and the body weight of that group was comparable $(P=0.119)$ to control birds $(2240 \pm 49 \mathrm{~g})$. Interestingly, addition of probiotic to the diet of broilers reared without stress application increased $(P<0.05)$ the $\mathrm{BW}$ of broilers at fourth, fifth and sixth week $(1544 \pm 24,2076 \pm 42$ and $27195 \pm 54 \mathrm{~g}$, respectively) compared with their control 
partners $(1476 \pm 29,1967 \pm 41$ and $2240 \pm 49$

$\mathrm{g}$, respectively). Table (3).

Table (3): Impacts of probiotic on body weight (g) of broilers with or without stress.

\begin{tabular}{|c|c|c|c|c|c|}
\hline $\begin{array}{c}\text { Age } \\
\text { (weeks) }\end{array}$ & $\begin{array}{c}\text { Control } \\
\text { group } \\
(\mathrm{n}=30) \\
\end{array}$ & $\begin{array}{c}\text { Heat stress } \\
\text { group } \\
(\mathbf{n}=\mathbf{3 0})\end{array}$ & $\begin{array}{c}\text { Heat stress } \\
+ \text { probiotic } \\
(n=30)\end{array}$ & $\begin{array}{c}\text { Probiotic } \\
\text { group } \\
(\mathbf{n}=\mathbf{3 0})\end{array}$ & $\begin{array}{c}P \\
\text { value }\end{array}$ \\
\hline 1 & $235 \pm 7^{a}$ & $240 \pm 5^{\mathrm{a}}$ & $243 \pm 4^{a}$ & $239 \pm 5^{a}$ & 0.079 \\
\hline 2 & $458 \pm 11^{b}$ & $450 \pm 10^{\mathrm{ab}}$ & $471 \pm 7^{b}$ & $466 \pm 9^{b}$ & 0.030 \\
\hline 3 & $850 \pm 21^{a b}$ & $863 \pm 16^{b}$ & $873 \pm 14^{b}$ & $854 \pm 16^{a b}$ & 0.070 \\
\hline 4 & $1476 \pm 29^{a}$ & $1457 \pm 24^{a}$ & $1478 \pm 22^{\mathrm{ab}}$ & $1544 \pm 24^{b}$ & 0.003 \\
\hline 5 & $1967 \pm 41^{b}$ & $1802 \pm 28^{a}$ & $1856 \pm 33^{a}$ & $2076 \pm 42^{c}$ & 0.001 \\
\hline 6 & $2240 \pm 49^{b}$ & $1883 \pm 31^{\mathrm{a}}$ & $2332 \pm 28^{b}$ & $2719 \pm 54^{c}$ & 0.001 \\
\hline
\end{tabular}

a,b,c Values within the same row with different letters are significantly different $(\mathrm{P}<0.05)$.

\section{I.2- Body weight gain (BWG):}

During the first 4 weeks there was no difference in BWG between groups $(\mathrm{P}>$ 0.05). At the fifth week, HS decreased the BWG $(345 \pm 10 \mathrm{~g})$ compared with control birds $(491 \pm 50 \mathrm{~g})$. At marketing age (week $6)$, birds reared under HS showed a reduction $(\mathrm{P}<0.05)$ in the $\mathrm{BWG}(145 \pm 37$ g) compared with control birds $(260 \pm 64 \mathrm{~g})$ but not reach significance. Moreover, addition of probiotic to the diet of broilers reared under heat stress $(544 \pm 44 \mathrm{~g})$ increased significantly BWG compared with control birds $(260 \pm 64 \mathrm{~g})$. As well as, feeding of probiotic to birds without stress increased BWG $(\mathrm{P}=0.001)(676 \pm 62 \mathrm{~g})$ compared with control birds $(260 \pm 64 \mathrm{~g})$. Table (4).

Table (4): Impacts of probiotic on the body weight gain (g) of broilers with or without stress.

\begin{tabular}{|c|c|c|c|c|c|}
\hline $\begin{array}{c}\text { Age } \\
\text { (weeks) }\end{array}$ & $\begin{array}{l}\text { Control } \\
\text { group } \\
(\mathbf{n}=30)\end{array}$ & $\begin{array}{l}\text { Heat stress group } \\
\qquad(\mathbf{n}=\mathbf{3 0})\end{array}$ & $\begin{array}{c}\text { Heat stress } \\
+ \text { probiotic } \\
\quad(n=30)\end{array}$ & $\begin{array}{l}\text { Probiotic group } \\
\qquad(\mathbf{n}=\mathbf{3 0})\end{array}$ & $\begin{array}{c}\mathbf{P} \\
\text { value }\end{array}$ \\
\hline 1 & $181 \pm 6.59^{a}$ & $181 \pm 6^{a}$ & $186 \pm 4^{a}$ & $186 \pm 5^{a}$ & 0.950 \\
\hline 2 & $223 \pm 14^{\mathrm{a}}$ & $210 \pm 11^{\mathrm{a}}$ & $228 \pm 45^{a}$ & $227 \pm 10^{\mathrm{a}}$ & 0.849 \\
\hline 3 & $392 \pm 25^{a}$ & $413 \pm 18^{a}$ & $402 \pm 18^{a}$ & $388 \pm 19^{a}$ & 0.790 \\
\hline 4 & $717 \pm 39^{a b}$ & $664 \pm 12^{a c}$ & $676 \pm 15^{\mathrm{ac}}$ & $760 \pm 25^{b}$ & 0.007 \\
\hline 5 & $491 \pm 50^{a}$ & $345 \pm 10^{b}$ & $378 \pm 14^{b}$ & $532 \pm 45^{a}$ & 0.001 \\
\hline 6 & $260 \pm 64^{b}$ & $145 \pm 37^{b}$ & $544 \pm 44^{\mathrm{a}}$ & $676 \pm 62^{a}$ & 0.001 \\
\hline
\end{tabular}

a,b,c,d Values within the same row with different letters are significantly different $(P<0.05)$. 


\section{I.3- Feed intake (FI):}

At the marketing age (week 6), birds under HS showed a numerical decreased FI than control (729 versus $1187 \mathrm{~g}$, respectively) and addition of probiotic to the diet of heat stressed broilers didn't increase FI $(835 \mathrm{~g})$ than control (1187 g) but it was higher than heat stressed birds without probiotic feeding (835 versus 729 $\mathrm{g}$ respectively). Table (5).

Table (5): Feed intake (g / bird / week) of broilers fed with or without probiotic and reared with or without stress.

\begin{tabular}{ccccc}
\hline $\begin{array}{c}\text { Age } \\
(\text { weeks })\end{array}$ & $\begin{array}{c}\text { Control } \\
\text { group } \\
(\mathbf{n}=30)\end{array}$ & $\begin{array}{c}\text { Heat stress group } \\
(\mathbf{n}=30)\end{array}$ & $\begin{array}{c}\text { Heat stress } \\
+ \text { probiotic } \\
(\mathbf{n}=30)\end{array}$ & $\begin{array}{c}\text { Probiotic group } \\
(\mathbf{n}=\mathbf{3 0})\end{array}$ \\
\hline 1 & $\mathbf{2 0 6}$ & $\mathbf{2 0 8}$ & $\mathbf{2 0 7}$ & $\mathbf{2 0 4}$ \\
\hline 2 & $\mathbf{4 6 6}$ & $\mathbf{4 6 0}$ & $\mathbf{3 9 9}$ & 454 \\
\hline 3 & 931 & $\mathbf{8 6 0}$ & $\mathbf{8 2 7}$ & $\mathbf{8 6 3}$ \\
\hline 4 & $\mathbf{9 2 8}$ & $\mathbf{8 6 3}$ & $\mathbf{8 3 2}$ & $\mathbf{8 8 8}$ \\
\hline 5 & 982 & $\mathbf{8 1 9}$ & $\mathbf{7 9 9}$ & $\mathbf{9 8 6}$ \\
\hline 6 & 1187 & 729 & 835 & 1165 \\
\hline
\end{tabular}

\section{4- Feed conversion ratio $(F C R)$ :}

At the $5^{\text {th }}$ and $6^{\text {th }}$ weeks, broilers reared under HS have an increased FCR (2.37 and 9.04 respectively) than control birds (1.99 and 4.36 respectively) and probiotic addition to birds at HS decreased FCR compared with heat stressed birds (2.11 and 1.75 versus 2.37 and 9.04 respectively).
Probiotic addition decreased FCR of heat stressed broilers at week 6 compared with control (1.75 versus 4.36 respectively). Addition of probiotic to birds reared without stress clearly decreased FCR at marketing age (week 6) (1.81versus 4.36 respectively). Table (6)

Table (6): Feed conversion ratio (FCR) of broilers fed with or without probiotic and reared either with or without stress.

\begin{tabular}{ccccc}
\hline $\begin{array}{c}\text { Age } \\
\text { (weeks) }\end{array}$ & $\begin{array}{c}\text { Control group } \\
(\mathbf{n}=30)\end{array}$ & $\begin{array}{c}\text { Heat stress group } \\
(\mathbf{n}=30)\end{array}$ & $\begin{array}{c}\text { Heat stress } \\
+ \text { probiotic } \\
(\mathbf{n}=30)\end{array}$ & $\begin{array}{c}\text { Probiotic group } \\
(\mathbf{n}=30)\end{array}$ \\
\hline 1 & 1.11 & 1.09 & 1.07 & 1.08 \\
\hline 2 & 2.09 & 2.17 & 1.75 & 2.00 \\
\hline 3 & 2.37 & 2.09 & 2.05 & 2.22 \\
\hline 4 & 1.48 & 1.45 & 1.37 & 1.28 \\
\hline 5 & 1.99 & 2.37 & 2.11 & 1.85 \\
\hline 6 & 4.36 & 9.04 & 1.75 & 1.81 \\
\hline
\end{tabular}

\section{Carcass traits and organs weights:}

Broilers reared under heat stress have significantly $(\mathrm{P}<0.05)$ lower carcass weight and eviscerated carcass weight $(1748.5 \pm 35.12$ and $1450.0 \pm 28.62 \mathrm{~g}$, respectively) compared with control 
broilers and addition of probiotic to diet of heat stressed birds significantly increased carcass weight and eviscerated carcass weight $(2165.5 \pm 24.39$ and $1825.0 \pm 23.10 \mathrm{~g}$ respectively) compared with control broilers $(2054.5 \pm 44.71$ and $1717.0 \pm 44.02 \mathrm{~g}$ respectively) as well as, heat stressed birds without probiotic feeding (1748.5 \pm 35.12 and $1450.0 \pm 28.62 \mathrm{~g}$ respectively). Addition of probiotic to diet of birds reared without stress significantly increased carcass weight and eviscerated carcass weight $(2523.5 \pm 50.27$ and $2115.0 \pm 42.57 \mathrm{~g}$ respectively) compared with control broilers (2054.5 \pm 44.71 and $1717.0 \pm 44.02 \mathrm{~g}$ respectively). Table (7).

Heat stressed broilers when fed with probiotic didn't differ spleen weight $(\mathrm{P}=$ $0.963)$ from control broilers $(2.81 \pm 0.25$ versus $2.80 \pm 0.16 \mathrm{~g}$ respectively). Addition of probiotic to diet of broilers reared without stress increased spleen weight compared with control $(3.26 \pm 0.23$ versus $2.80 \pm 0.16 \mathrm{~g}$ respectively) but this difference didn't reach significance $(\mathrm{P}=$ 0.156). Table (7).

Heat stressed broilers showed a significant decreased $(\mathrm{P}<0.05)$ heart weight compared with control birds (7.74 \pm 0.37 versus $10.38 \pm 0.6 \mathrm{~g}$ respectively) while addition of probiotic to diet of heat stressed birds increased heart weight to be comparable with control birds $(9.50 \pm 0.40$ versus $10.38 \pm 0.6 \mathrm{~g}$ respectively) and higher than heat stressed birds $(9.50 \pm 0.40$ versus $7.74 \pm 0.37 \mathrm{~g}$ respectively). Addition of probiotic to broilers reared without stress significantly increased heart weight $(\mathrm{P}=$ 0.010) compared with control birds $(12.49 \pm 0.56$ versus $10.38 \pm 0.6 \mathrm{~g}$ respectively) Table (7).

Heat-stressed birds showed a decreased liver weight $(31.71 \pm 1.94 \mathrm{~g})$ compared with control birds $(37.14 \pm 1.09 \mathrm{~g})$ while addition of probiotic to the diet of heat stressed broilers increased liver weight $(38.95 \pm 1.34$ g) to be comparable with control birds $(37.14 \pm 1.09 \mathrm{~g})$ and significantly higher $(\mathrm{P}$ $=0.031)$ than heat stressed birds
$(31.71 \pm 1.94 \mathrm{~g})$. Addition of probiotic to diet of broilers reared without stress significantly increased $(P=0.010)$ liver weight compared with control birds $(46.78 \pm 1.61$ versus $37.14 \pm 1.09 \mathrm{~g}$ respectively) Table (7).

Heat stressed broilers have a decreased $(\mathrm{P}<0.05)$ gizzard weight $(32.63 \pm 2.09 \mathrm{~g})$ compared with control birds $(39.30 \pm 1.55 \mathrm{~g})$ but, addition of probiotic to heat stressed birds showed an increased gizzard weight $(35.50 \pm 1.71 \mathrm{~g})$ to be comparable with control $(39.30 \pm 1.55 \mathrm{~g})$ and higher than heat stressed without probiotic feeding $(35.50 \pm 1.71$ versus $32.63 \pm 2.09 \quad \mathrm{~g}$ respectively) but this difference didn't reach significance $(\mathrm{P}=0.109)$. Table $(7)$.

\section{3- Clinical serum parameters:}

Heat stressed broilers showed a decreased $(\mathrm{P}=0.001)$ total protein $(1.31 \pm 0.02 \mathrm{~g} / \mathrm{dl})$ compared with control birds $(2.50 \pm 0.14 \mathrm{~g} / \mathrm{dl})$ and addition of probiotic to diet of heat stressed broilers significantly increased $(\mathrm{P}<0.05)$ total protein $(1.78 \pm 0.05 \mathrm{~g} / \mathrm{dl})$ compared with heat stressed birds without probiotic feeding $(1.31 \pm 0.02 \mathrm{~g} / \mathrm{dl})$ and significantly decreased $(\mathrm{P}=0.001)$ total protein than control birds $(1.78 \pm 0.05$ versus $2.50 \pm 0.14$ $\mathrm{g} / \mathrm{dl}$ respectively). Interestingly, addition of probiotic to diet of broilers reared without stress significantly increased total protein $(\mathrm{P}=0.043)$ compared with control birds $(2.83 \pm 0.14 \quad$ versus $2.50 \pm 0.14 \quad \mathrm{~g} / \mathrm{dl}$ respectively) Table (8).

Addition of probiotic to diet of birds reared without stress showed a significant increase $(\mathrm{P}=0.043)$ in serum albumin level $(1.42 \pm 0.03 \mathrm{~g} / \mathrm{dl})$ compared with control birds (1.21 $\pm 0.09 \mathrm{~g} / \mathrm{dl})$ Table (8).

While heat stressed birds have a decreased serum globulin $(\mathrm{P}<0.05)$ $(0.11 \pm 0.02 \mathrm{~g} / \mathrm{dl})$ compared with control $(1.29 \pm 0.07 \mathrm{~g} / \mathrm{dl})$ and addition of probiotic to diet of heat stressed birds significantly increased $(\mathrm{P}<0.05)$ globulin $(0.57 \pm 0.07$ $\mathrm{g} / \mathrm{dl})$ compared with heat stressed birds 
without probiotic feeding $(0.11 \pm 0.02 \mathrm{~g} / \mathrm{dl})$ but globulin concentration still significantly lower $(\mathrm{P}=0.001)$ than control birds $(1.29 \pm 0.07 \mathrm{~g} / \mathrm{dl})$ Table (8).

Albumin/Globulin ratio $(\mathrm{A} / \mathrm{G})$ ratio of heat stressed birds was significant higher $(\mathrm{P}$ $=0.001)(15.21 \pm 4.97)$ compared with heat stressed birds with probiotic $(2.34 \pm 0.43)$ and control birds $(0.94 \pm 0.06)$ Table (8).

Heat stressed broilers showed a significant increased $(\mathrm{P}<0.05)$ in serum cholesterol level $(148.58 \pm 0.92 \mathrm{mg} / \mathrm{dl})$ compared with control birds $(112.03 \pm 1.14$ $\mathrm{g} / \mathrm{dl}$ ) while addition of probiotic to diet of heat stressed birds reduced and normalized cholesterol level to be comparable $(\mathrm{P}=$ $0.786)$ with control birds (112.71 \pm 2.77 versus $112.03 \pm 1.14 \mathrm{mg} / \mathrm{dl}$ respectively). Addition of probiotic to diet of birds reared without stress significantly decreased $(\mathrm{P}=$ 0.001) cholesterol $(99.20 \pm 2.7 \quad \mathrm{mg} / \mathrm{dl})$ compared with control birds $(112.03 \pm 1.14$ $\mathrm{mg} / \mathrm{dl})$ Table (8).

Table (7): Carcass and absolute internal organ weights (g) of broilers fed with or without probiotic and reared either with or without stress.

\begin{tabular}{|c|c|c|c|c|c|}
\hline & $\begin{array}{c}\text { Control } \\
\text { group } \\
(n=10) \\
\end{array}$ & $\begin{array}{c}\text { Heat stress } \\
\text { group } \\
(\mathbf{n}=10)\end{array}$ & $\begin{array}{c}\text { Heat stress + } \\
\text { probiotic } \\
(n=10) \\
\end{array}$ & $\begin{array}{c}\text { Probiotic } \\
\text { group } \\
(\mathbf{n}=10) \\
\end{array}$ & $\begin{array}{c}\mathbf{P} \\
\text { value }\end{array}$ \\
\hline Carcass weight & $2054.5 \pm 44.71^{b}$ & $1748.5 \pm 35.12^{a}$ & $2165.5 \pm 24.39^{c}$ & $2523.5 \pm 50.27^{d}$ & 0.030 \\
\hline $\begin{array}{c}\text { Eviscerated } \\
\text { carcass weight }\end{array}$ & $1717.0 \pm 44.02^{b}$ & $1450.0 \pm 28.62^{a}$ & $1825.0 \pm 23.10^{c}$ & $2115.0 \pm 42.57^{d}$ & 0.049 \\
\hline Spleen weight & $2.80 \pm 0.16^{\mathrm{ab}}$ & $2.42 \pm 0.34^{\mathrm{a}}$ & $2.81 \pm 0.25^{\mathrm{ab}}$ & $3.26 \pm 0.23^{b}$ & 0.790 \\
\hline Heart weight & $10.38 \pm 0.6^{c}$ & $7.74 \pm 0.37^{a}$ & $9.50 \pm 0.40^{b c}$ & $12.49 \pm 0.56^{d}$ & 0.007 \\
\hline Liver weight & $37.14 \pm 1.09^{b c}$ & $31.71 \pm 1.94^{\mathrm{a}}$ & $38.95 \pm 1.34^{c}$ & $46.78 \pm 1.61^{d}$ & 0.001 \\
\hline Gizzard weight & $39.30 \pm 1.55^{b c}$ & $32.63 \pm 2.09^{a}$ & $35.50 \pm 1.71^{\mathrm{ab}}$ & $41.59 \pm 2.09^{c}$ & 0.001 \\
\hline
\end{tabular}

$\overline{\mathrm{a}, \mathrm{b}, \mathrm{c}, \mathrm{d}}$ Values within the same row with different letters are significantly different $(P<0.05)$.

Addition of probiotic to diet of heat stressed birds increased creatinine $(\mathrm{P}<$ 0.05) compared with control $(0.44 \pm 0.05$ versus $0.26 \pm 0.06 \mathrm{mg} / \mathrm{dl}$ respectively) and heat stressed birds without probiotic feeding $(0.44 \pm 0.05$ versus $0.26 \pm 0.04 \mathrm{mg} / \mathrm{dl}$ respectively). Table (8).

Addition of probiotic to diet of heat stressed birds increased urea concentration $(\mathrm{P}=0.037)$ compared with heat stressed birds without probiotic feeding $(4.20 \pm 0.20$ versus $2.40 \pm 0.67 \mathrm{mg} / \mathrm{dl}$ respectively) but not differ $(\mathrm{P}=0.468)$ from control birds $(4.20 \pm 0.20$ versus $3.60 \pm 0.92 \mathrm{mg} / \mathrm{dl}$ respectively). Table (8).

As well as, addition of probiotic to diet of heat stressed birds increased AST level $(\mathrm{P}=0.002) \quad(276.40 \pm 20.84 \mathrm{mg} / \mathrm{dl})$ compared with control birds (193.00 \pm 7.20 $\mathrm{IU} / \mathrm{dl})$ but not differ $(\mathrm{P}=0.198)$ from heat stressed birds without probiotic feeding (276.40 \pm 20.84 versus $243.80 \pm 13.89 \mathrm{IU} / \mathrm{dl}$ respectively). Addition of probiotic to diet of birds reared without stress significantly increased $(\mathrm{P}=0.014)$ AST level compared with control birds $(258.60 \pm 26.17$ versus 193.00 $\pm 7.20 \mathrm{IU} / \mathrm{dl}$ respectively) Table (8).

Serum alanine aminotransferase (ALT) level didn't differ between experimental groups $(\mathrm{P}=0.186)$. Similarly, serum glucose didn't show significant differences between treatments $(\mathrm{P}=0.218)$ Table $(8)$.

\section{4- Thyroid hormones:}

Broilers fed with or without probiotic and reared with or without stress showed no significant differences $(\mathrm{P}>0.05)$ between them when compared with control birds in the level of T3. Table (8). 
Heat stressed broilers have higher T4 $(\mathrm{P}=0.001)(3.43 \pm 0.03 \mu \mathrm{g} / \mathrm{dl})$ compared with control birds $(2.20 \pm 0.16 \mathrm{ug} / \mathrm{dl})$ and addition of probiotic to their diet significantly decreased $(\mathrm{P}<0.05) \mathrm{T} 4$ level $(2.87 \pm 0.15 \mu \mathrm{g} / \mathrm{dl})$ compared with heat stressed birds without probiotic feeding
$(3.43 \pm 0.03$ respectively $\mu \mathrm{g} / \mathrm{dl})$ but higher than control birds $(2.87 \pm 0.15$ versus $2.20 \pm 0.16 \mu \mathrm{g} / \mathrm{dl}$ ). Addition of probiotic to broilers reared without stress increased $(\mathrm{P}=$ 0.006) $\mathrm{T} 4$ compared with control broilers $(2.81 \pm 0.11 \quad$ versus $2.20 \pm 0.16 \mu \mathrm{g} / \mathrm{dl}$ respectively). Table (8).

Table (8): Clinical serum biochemicals and thyroid hormones of broilers fed with or without probiotic reared either with or without stress.

\begin{tabular}{|c|c|c|c|c|c|}
\hline & $\begin{array}{c}\text { Control group } \\
(n=5)\end{array}$ & $\begin{array}{l}\text { Heat stress } \\
\text { group }(n=5)\end{array}$ & $\begin{array}{c}\text { Heat stress + } \\
\text { probiotic }(n=5)\end{array}$ & $\begin{array}{c}\text { Probiotic } \\
\text { group }(n=5)\end{array}$ & $\begin{array}{c}\mathbf{P} \\
\text { value }\end{array}$ \\
\hline Total Protein (g/dl) & $2.50 \pm 0.14^{c}$ & $1.31 \pm 0.02^{\mathrm{a}}$ & $1.78 \pm 0.05^{b}$ & $2.83 \pm 0.14^{d}$ & 0.001 \\
\hline Albumin (g/dl) & $1.21 \pm 0.09^{\mathrm{a}}$ & $1.19 \pm 0.03^{\mathrm{a}}$ & $1.21 \pm 0.03^{\mathrm{a}}$ & $1.42 \pm 0.03^{b}$ & 0.233 \\
\hline Globulin (g/dl) & $1.29 \pm 0.07^{\mathrm{c}}$ & $0.11 \pm 0.02^{\mathrm{a}}$ & $0.57 \pm 0.07^{b}$ & $1.41 \pm 0.14^{c}$ & 0.001 \\
\hline A/G ratio & $0.94 \pm 0.06^{a}$ & $15.21 \pm 4.97^{\mathrm{b}}$ & $2.34 \pm 0.43^{a}$ & $1.05 \pm 0.13^{a}$ & 0.001 \\
\hline Cholesterol (mg/dl) & $112.03 \pm 1.14^{\mathrm{bc}}$ & $148.58 \pm 0.92^{\mathrm{d}}$ & $112.71 \pm 2.77^{b c}$ & $99.20 \pm 2.7^{a}$ & 0.001 \\
\hline Creatinine (mg/dl) & $0.26 \pm 0.06^{\mathrm{a}}$ & $0.26 \pm 0.04^{\mathrm{a}}$ & $0.44 \pm 0.05^{b}$ & $0.32 \pm 0.05^{\mathrm{ab}}$ & 0.057 \\
\hline Urea (mg/dl) & $3.60 \pm 0.92^{\mathrm{ab}}$ & $2.40 \pm 0.67^{b}$ & $4.20 \pm 0.20^{\mathrm{a}}$ & $3.80 \pm 0.37^{\mathrm{ab}}$ & 0.282 \\
\hline AST (IU/dl) & $193.00 \pm 7.20^{\mathrm{a}}$ & $243.80 \pm 13.89^{\mathrm{abc}}$ & $276.40 \pm 20.84^{c}$ & $258.60 \pm 26.17^{b c}$ & 0.032 \\
\hline ALT (IU/dl) & $19.20 \pm .86^{\mathrm{ab}}$ & $22.40 \pm 2.03^{a b}$ & $17.60 \pm .92^{b}$ & $23.20 \pm 3.33^{a}$ & 0.186 \\
\hline Glucose (mg/dl) & $136.60 \pm 18.93^{\mathrm{ab}}$ & $167.80 \pm 18.38^{b}$ & $144.20 \pm 11.51^{\mathrm{ab}}$ & $119.80 \pm 14.96^{\mathrm{a}}$ & 0.218 \\
\hline T3 (ng/ml) & $1.38 \pm 0.32^{\mathrm{a}}$ & $1.57 \pm 0.17^{a}$ & $1.57 \pm 0.07$ a & $1.28 \pm 0.28^{a}$ & 0.919 \\
\hline $\mathrm{T} 4(\mu \mathrm{g} / \mathrm{dl})$ & $2.20 \pm 0.16^{a}$ & $3.43 \pm 0.03^{c}$ & $2.87 \pm 0.15^{b}$ & $2.81 \pm 0.11^{b}$ & 0.001 \\
\hline
\end{tabular}

\section{Discussion}

Rearing of broilers under heat stress is one of the main problems facing poultry industry especially in tropical countries such as Egypt. However, there are limited data concerning the adverse impacts higher temperature on productivity, carcass characteristics, and clinical serum biochemicals in broilers. Therefore, this study was performed to address the adverse effects of heat stress on performance, carcass traits, and clinical serum biochemicals in broiler chickens. The results of the current study showed that HS $\left(32-35^{\circ} \mathrm{C}\right)$ adversely affect the performance, carcass traits and clinical health parameters of broilers resulting in lower feed intake and decreased final body weight. Heat stress has a higher adverse effect on birds' performance, in addition to its higher alteration of health parameters of broiler chickens in this study. The decreased feed intake was the actual cause for reduction of growth broilers reared under HS. It was shown that increased environmental temperature stimulates the peripheral thermal receptors to transmit suppressive nerve impulse to the appetite center in the hypothalamus causing a decrease in feed consumption (Leeson et al., 1992). Another explanation is that 
body weight may decrease during heat stress due to the expenditure of higher energy to maintain their body temperature in addition to their lowered feed intake and this agreed with the inference of Sritharet et al. (2002).

In the present experiment, carcass traits and internal organ weights as important health indicators were significantly changed due to stress. In focus, the reduced carcass weight and eviscerated carcass weight were recorded. These results are in the agreement with Kucuk et al. (2003) and Akşit et al. (2006). The poor carcass characteristics may be due to a reduced feed intake and impaired utilization of nutrients. The liver, being one of the most vital organs of the body, constitutes the lifeline system of birds. This organ also plays a major role in the detoxification, digestion, metabolism and utilization of feed nutrients as a center of a number of digestive, metabolic, and productive activities, this vital immune organ in the body showed atrophy due to HS. This result was previously observed by Kucuk et al. (2003) and Ahmed and ElGhamdi (2008), this can be explained as cardiovascular adjustment in response to HS include vasodilatation in the cutaneous vascular bed and vasoconstriction in hepato-splanchnic vascular area (Richardson et al., 1991) leading to fatty and parenchymatus degeneration of the hepatocyte that was manifested by shrinkage in the liver size (Sritharet et al., 2002). As well as, gizzard and heart weights were decreased by $\mathrm{HS}$, these results were observed earlier by Kucuk et al., (2003) and Keambou et al., (2014).

In the current study, the health status of birds was estimated by measurement of clinical serum biochemicals. Heat stress decreased the concentration of circulating total protein and globulins, suggesting that higher temperature alters the protein metabolism (Attia et al., 2011, Sujatha et al., 2010, Rehab, 2011). Moreover, cholesterol was also increased in the blood of heat stressed birds as discussed before (Rehab, 2011, Sujatha et al., 2010). The results of this study didn't find any effect of heat stress on other blood parameters as creatinine, urea, ALT, AST and glucose. These findings were also observed previously by Imik et al. (2013) and Tollba and Mahmoud (2009). Furthermore, HS increased serum concentration of $\mathrm{T} 4$. It was shown that when chickens are exposed to warm temperatures, T4 was inactivated by conversion into reverse T3 (r-T3). The circulating serum T4 level depends on both the rate of secretion and the rate of utilization of T4 (McFarland et al., 1966). Such a decrease in T4 utilization could possibly explain the higher circulating $\mathrm{T} 4$ levels found at $32-35^{\circ} \mathrm{C}$ in the present study. Also, the elevated level of total T4 of heat-exposed birds was reported by Moss and Balnave (1978) and this could be related to a reduction in its utilization. Another explanation is that the reduction in feed intake observed in heat stressed birds at the higher temperature may be a contributing factor in determining the higher T4 levels at $32-35^{\circ} \mathrm{C}$. In general, all these adverse effects were the main causes of reducing the performance of broilers.

Probiotic (PROBAC plus) $(1 \mathrm{~g} / \mathrm{kg}$ diet) was added to the diet of stressed birds as an important solution to counteract the adverse effects of heat stress on performance of birds. This may be related to maintaining normal intestinal micro flora by competitive exclusion and antagonism, altering metabolism by increasing digestive enzyme activities and by promoting digestion rate of nutrient (Apata, 2008, Nahashon et al., 1992) also the direct effect of probiotic by stimulating appetite of the host (Nahashon et al., 1992, Nahashon et al., 1993). It is known that, the role of probiotic in overcoming the 
adverse effect of stress resulted in an improved health status of broilers as revealed in that study through improving FI, BW, BWG, and FC. This also was previously reported by Haldar et al. (2011) who used the same level of probiotic (1 $\mathrm{g} / \mathrm{kg}$ diet). Moreover, carcass weight and eviscerated carcass weight were increased due to feeding of probiotic to stress birds to be comparable to the control birds. Similar results were already recorded previously using dose of ( $2 \mathrm{~g}$ probiotic/ $\mathrm{kg}$ diet) by Tollba and Mahmoud (2009). As well as, probiotic feeding to stressed birds resulted in an increased heart weight. This finding is similar to previous finding (AlDaraji, 2012).

Supplementation of the diet of stressed birds with probiotic is able to correct the adverse effect of stress on physiological and clinical serum biochemicals parameters. Feeding probiotic to heat stressed birds resulted in higher total protein and globulin, suggesting stimulation of protein metabolism and due to higher body weight. These results were also observed where the probiotic level was $2 \mathrm{~g} / \mathrm{kg}$ diet by Tollba and Mahmoud (2009) and Rehab (2011). Probiotic supplementation to the diet of stressed birds decreased the cholesterol level to be comparable to the control birds which was also recorded by Sohail et al. (2010) who used $0.1 \%$ probiotic supplemented to the basal diet. This reduction may be due to the incorporation of cholesterol into the cellular membrane of the organism by the probiotic; thus, cholesterol assimilation by Lactobacillus in turn reduces cholesterol absorption in the system (Gilliland et al., 1985). Furthermore, probiotic supplementation improved $\mathrm{T} 4$ of stressed birds due to enhancing the activity of corticotrophin releasing factor (CRF), which is known to stimulate thyrotropin secretion and hence, T4 secretion (Geris et al., 1996, Geris et al., 1999). Also, this enhancement was recorded by using $0.1 \%$ probiotic supplemented to the basal diet (Sohail et al., 2010). Finally, addition of probiotic to the diet of stressed broilers has the ability to enhance and counteract the adverse effects of $\mathrm{HS}$ and is beneficial as anti-stress feed additive.

\section{Conclusion}

From the results of this study, it can be concluded that rearing of birds under high environmental temperature $\left(32-35^{\circ} \mathrm{C}\right)$ above the comfort zone $\left(22-27^{\circ} \mathrm{C}\right)$ led to heat stress that caused obvious negative effects on the growth performance and caused a significant adverse alteration in the physiology of birds resulting in poor productivity and growth. Probiotic feeding improved birds' performance and corrected the physiological alteration occurred due to stress. Most importantly, addition of probiotic to diets of birds reared without stress improved their performance and health. Thus, probiotic PROBAC plus ${ }^{\circledR}$ $(1 \mathrm{~g} / \mathrm{kg}$ diet $)$ was beneficial in counteracting the adverse effects of heat stress on health and growth performance. Additionally, PROBAC plus ${ }^{\circledR}$ feeding can be used as a growth promoter to increase the productivity of broilers.

\section{Conflict of interest statement}

The authors declare that they have no conflict of interest.

\section{References}

Abdel-Wareth A, Hassan H, Abdelrahman $\mathrm{W}$, Ismail $\mathrm{Z}$, Ali $\mathrm{R}$, Ahmed $\mathrm{E}$, Lohakare J (2018). Growth performance, carcass criteria, and serum biochemical parameters of broiler chickens supplemented with either synbiotic or prebiotic under hot climatic conditions. British Poultry Science, 59: 663-668. 
Ahmed ZA, El-Ghamdi ZH (2008). Multiple environmental stresses and broiler internal organs somatic indices under controlled environment. International Journal of Poultry Science, 7: 1089-1094.

Akşit M, Yalcin S, Özkan S, Metin K, Özdemir D (2006). Effects of temperature during rearing and crating on stress parameters and meat quality of broilers. Poultry Science, 85: 1867-1874.

Al-Daraji H (2012). The use of liquorice, probiotic, potassium chloride and sodium bicarbonate to counteract the detrimental effects of heat stress on performance of broilers. Global Advanced Research Journal of Agricultural Science, 1.

Apata D (2008). Growth performance, nutrient digestibility and immune response of broiler chicks fed diets supplemented with a culture of Lactobacillus bulgaricus. Journal of the Science of Food and Agriculture, 88: 1253-1258.

Attia Y, Hassan R, Tag El-Din A, AbouShehema B (2011). Effect of ascorbic acid or increasing metabolizable energy level with or without supplementation of some essential amino acids on productive and physiological traits of slowgrowing chicks exposed to chronic heat stress. Journal of Animal Physiology and Animal Nutrition, 95: 744-755.

Cramer T, Kim H, Chao Y, Wang W, Cheng H, Kim Y (2018). Effects of probiotic (Bacillus subtilis) supplementation on meat quality characteristics of breast muscle from broilers exposed to chronic heat stress. Poultry science, 97: 3358-3368.
Dibaji SM, Seidavi A, Asadpour L, Moreira da Silva F (2014). Effect of a synbiotic on the intestinal microflora of chickens. Journal of Applied Poultry Research, 23: 1-6.

Eckert N, Lee J, Hyatt D, Stevens S, Anderson S, Anderson P, Beltran R, Schatzmayr G, Mohnl M, Caldwell D (2010). Influence of probiotic administration by feed or water on growth parameters of broilers reared on medicated and nonmedicated diets. Journal of Applied Poultry Research, 19: 5967.

Farghly MF, Mahrose KM, Galal AE, Ali RM, Ahmad EA, Rehman ZU, Ullah Z, Ding C (2018). Implementation of different feed withdrawal times and water temperatures in managing turkeys during heat stress. Poultry Science, 97: 3076-3084.

Geris K, Kotanen S, Berghman L, Kühn E, Darras V (1996). Evidence of a thyrotropin-releasing activity of ovine corticotropin-releasing factor in the domestic fowl (Gallus domesticus). General and Comparative Endocrinology, 104:139-146.

Geris K, Laheye A, Berghman L, Kühn E, Darras V (1999). Adrenal inhibition of corticotropin-releasing hormoneinduced thyrotropin release: A comparative study in pre-and posthatch chicks. Journal of Experimental Zoology, 284: 776782.

Ghareeb K, Awad WA, Sid-Ahmed OE, Böhm J (2014). Insights on the host stress, fear and growth responses to the deoxynivalenol feed contaminant in broiler chickens. PloS one, 9, e87727. 
Ghazi S, Habibian M, Moeini M, Abdolmohammadi, A (2012). Effects of different levels of organic and inorganic chromium on growth performance and immunocompetence of broilers under heat stress. Biological trace element research, 146: 309-317.

Gilliland S, Nelson C, Maxwell C (1985). Assimilation of cholesterol by Lactobacillus acidophilus. Applied and Environmental Microbiology, 49: 377-381.

Habeeb A, Gad A, Atta A (2018). Temperature-humidity indices as indicators to heat stress of climatic conditions with relation to production and reproduction of farm animals. International Journal of Biotechnology and Recent Advances, 1: 35-50.

Haldar S, Ghosh T, Bedford M (2011). Effects of yeast (Saccharomyces cerevisiae) and yeast protein concentrate on production performance of broiler chickens exposed to heat stress and challenged with Salmonella enteritidis. Animal Feed Science and Technology, 168: 61-71.

Hao H, Sander P, Iqbal Z, Wang Y, Cheng G, Yuan Z (2016). The risk of some veterinary antimicrobial agents on public health associated with antimicrobial resistance and their molecular basis. Frontiers in microbiology, 7: 1626.

He S, Arowolo M, Medrano R, Li S, Yu Q, Chen J, He J (2018). Impact of heat stress and nutritional interventions on poultry production. World's Poultry Science Journal, 74: 647664.

Imik H, Kaynar O, Ozkanlar S, Gumus R, Polat H, Ozkanlar Y (2013). Effects of vitamin $\mathrm{C}$ and $\alpha$-lipoid acid dietary supplementations on metabolic adaptation of broilers to heat stress. Revue Méd Vét, 164: 52-59.

Kucuk O, Sahin N, Sahin K (2003). Supplemental zinc and vitamin A can alleviate negative effects of heat stress in broiler chickens. Biological trace element research, 94: 225-235.

Leeson S, Summers J, Caston L (1992). Response of broilers to feed restriction or diet dilution in the finisher period. Poultry science, 71 : 2056-2064.

Mahrose KM, ELHACK ME, MAHGOUB SA, ATTIA FA (2019). Influences of stocking density and dietary probiotic supplementation on growing Japanese quail performance. Anais da Academia Brasileira de Ciências, 91.

McEwen SA, Angulo FJ, Collignon PJ, Conly JM (2018). Unintended consequences associated with national-level restrictions on antimicrobial use in food-producing animals. The Lancet Planetary Health, 2, e279-e282.

McFarland LZ, Yousef MK, Wilson WO (1966). The influence of ambient temperature and hypothalamic lesions on the disappearance rates of thyroxine-I 131 in the Japanese quail. Life sciences, 5: 309-315.

Mohammed A, Jiang S, Jacobs J, Cheng H (2019). Effect of a synbiotic supplement on cecal microbial ecology, antioxidant status, and immune response of broiler chickens reared under heat stress. Poultry science.

Moss B, Balnave D (1978). The influence of elevated environmental temperature and nutrient intake on thyroid status and hepatic enzyme activities in immature male chicks. Comparative Biochemistry and 
Physiology Part B: Comparative Biochemistry, 60: 157-161.

Nahashon S, Nakaue H, Mirosh L (1992). Effect of direct-fed microbials on nutrient retention and production parameters of laying pullets. Poultry Science, 71: 111.

Nahashon S, Nakaue H, Mirosh L (1993). Effect of direct fed microbials on nutrient retention and productive parameters of Single Comb White Leghorn pullets. Poultry Science, 72: 87 .

NRC (1994). Nutrient requirements of poultry. National Research Council. National Academy Press Washington. eUSA USA.

Ohimain EI, Ofongo RT (2012). The effect of probiotic and prebiotic feed supplementation on chicken health and gut microflora: a review. International Journal of Animal and Veterinary Advanced, 4: 135-143.

Olanrewaju H, Thaxton J, Dozier W, Purswell J, Roush W, Branton S (2006). A review of lighting programs for broiler production. International Journal of Poultry Science, 5: 301-308.

Pournazari M, AA-Qotbi A, Seidavi A, Corazzin M (2017). Prebiotics, probiotics and thyme (Thymus vulgaris) for broilers: performance, carcass traits and blood variables. Revista Colombiana de Ciencias Pecuarias, 30: 3-10.

Purswell JL, Dozier III WA, Olanrewaju HA, Davis JD, Xin H, Gates RS (2012). Effect of temperaturehumidity index on live performance in broiler chickens grown from 49 to 63 days of age. IX International Livestock Environment Symposium (ILES IX), 2012. American Society of Agricultural and Biological Engineers, 3.
Rehab YMA (2011). Effect of vitamin C, E and probiotic additions under heat stress on productive performance, meat quality and immune responses of broiler chicks. Master, Animal And Poultry Production Department Faculty Of Agriculture, Damanhour University.

Rhoads RP, Baumgard LH, Suagee JK, Sanders SR (2013). Nutritional interventions to alleviate the negative consequences of heat stress. Advances in nutrition, 4: 267-276.

Richardson D, Hu Q, Shepherd S (1991). Effects of invariant sympathetic activity on cutaneous circulatory responses to heat stress. Journal of Applied Physiology, 71: 521-529.

Rocco RM (2005). Landmark papers in clinical chemistry, Elsevier.

Shah M, Zaneb H, Masood S, Khan RU, Mobashar M, Khan I, Din S, Khan MS, Rehman HU, Tinelli A (2019). Single or Combined Applications of Zinc and Multi-strain Probiotic on Intestinal Histomorphology of Broilers Under Cyclic Heat Stress. Probiotics and antimicrobial proteins, 1-8.

Sohail M, Ijaz A, Yousaf M, Ashraf K, Zaneb $\mathrm{H}$, Aleem $\mathrm{M}$, Rehman $\mathrm{H}$ (2010). Alleviation of cyclic heat stress in broilers by dietary supplementation of mannanoligosaccharide and Lactobacillusbased probiotic: Dynamics of cortisol, thyroid hormones, cholesterol, C-reactive protein, and humoral immunity. Poultry science, 89: 1934-1938.

Sritharet N, Hara H, Yoshida Y, Hanzawa K, Watanabe S (2002). Effects of Heat Stress on Histological Features in Pituicytes and Hepatocytes, and Enzyme Activities of Liver and Blood 
Plasma in Japanese quail (Coturnix japonica). The Journal of Poultry Science, 39: 167-178.

Sugiharto S, Yudiarti T, Isroli I, Widiastuti E, Kusumanti E (2017). Dietary supplementation of probiotics in poultry exposed to heat stress-a review. Annals of Animal Science, 17: 591-604.

Sujatha V, Korde JP, Rastogi SK (2010). Amelioration of heat stress induced disturbances of the antioxidant defense system in broiler.
Tao X, Xin H (2003). TemperatureHumidity-Velocity Index for market-size broilers.

Tollba A, Mahmoud R (2009). How to control the broiler pathogenic intestinal flora under normal or heat stress conditions. 1-Medical plantprobiotics-sand as a litter. Egyptian Poultry Science Journal, 29: 565587.

WHOLFAO (2001). Health and nutritional properties of probiotics in food including powder milk with live lactic acid bacteria. 